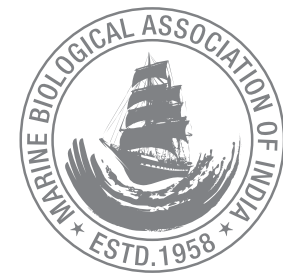

\title{
Conservation of seagrass beds with special reference to associated species and fishery resources
}

\author{
R. Jeyabaskaran*, J. Jayasankar, T. V. Ambrose, K. C. Vineetha Valsalan, N. D. Divya, N. Raji, \\ P. Vysakhan, Seban John, D. Prema, P. Kaladharan and V. Kripa \\ ICAR-Central Marine Fisheries Research Institute, P.O. Box 1603, Ernakulam North P.O, Kochi- 682018, Kerala, India. \\ *Correspondence e-mail: jbcmfri@gmail.com
}

\begin{abstract}
The southeast coast of India bordering Gulf of Mannar and Palk Bay has luxuriant growth of seagrass beds which sustain good fisheries and is a biodiversity hotspot. Many fishers living along the coast depend on these resources for their livelihood. Several species of invertebrates and vertebrates fully depend on the seagrass resources for their survival and sustenance. In this paper, the diversity of species commonly associated with the seagrass beds and their present status is presented followed by the fisheries associated with this ecosystem. The type of fishing activities including the details of crafts, gears, number of fishers involved and catch statistics are presented. The main objective of this approach is to understand how the fishing activities influence the ecosystem and fishermen. Underwater monitoring and visual observations were documented through photographs and videos. Artisanal fishing activities such as bottom set gillnet, push net, lead-fish trap net and shore seine are in detail discussed and the conservation measures which are urgently required are also presented.
\end{abstract}

Keywords: Dugong, artisanal fisheries, biodiversity, Gulf of Mannar, Palk Bay, fishermen profile

\section{Introduction}

Seagrass meadows are one of the most productive marine ecosystem in the world sustaining good fishery. They act as nursery, refuge and feeding ground for many marine fishes and invertebrates (Edgar and Shaw, 1995; Jackson et al., 2001). The seagrass beds also act as nursery grounds for larvae and juveniles of many fishes (Middleton et al., 1984; Olney and Boehlert, 1988; Bell and Pollard, 1989; Rooker et al., 1998). Many groups of zooplankton and phytoplankton have been observed to be part of the plankton community throughout the year and form a major food for commercially important fishes (Klumpp et al., 1989; Webb, 1991). The zooplankton density in sea grass beds have always been found to be higher and double than offshore area (Robertson et al., 1988). Sea grasses also form the important food to many species of echinoderms, molluscs, crustaceans and fishes (Waycotta et al., 2008). Several invertebrates like ascidians (Jeyabaskaran et al., 2014), cephalopods especially squid and cuttlefish utilize seagrass beds as spawning ground and attach their egg masses to seagrass blades (Blanc and Daguzan, 1998). Seagrass beds also support to mitigate climate change impacts. Their carbon sequestration is most effective and also enhances the fine sedimentation deposition for seafloor stabilization (Fonesca 
and Fisher, 1986; Fourqurean et al., 2012). Seagrass detritus contribute much for coastal nutrient recycling and indirectly promote good fishery (Jackson et al., 2001).

Seagrass beds are degrading fast all over the world. At global level seagrass beds have been vanishing at a rate of $110 \mathrm{~km}^{2}$ year ${ }^{1}$ since 1980 and $7 \%$ year $^{-1}$ since 1990 . The ecosystem services provided by the seagrass beds in the world have been estimated at \$1.9 trillion per year (Waycotta et al., 2008). Gulf of Mannar (GoM) and Palk Bay (PB) situated on the southeast coast of India have luxuriant seagrass beds which support good fishery of fin fishes and shellfishes. Many fishers living along the PB and GoM depend on these resources. Almost 96,735 fishermen from 288 fishing villages belonging to 6 districts in Tamilnadu are actively engaged in seagrass associated fisheries. The coral reef ecosystem in these areas has been extensively studied, however, information on biodiversity of seagrass associated animals and fisheries is limited. Seagrass beds of GoM and PB are degrading fast due to adverse fishing practices, pollution and other activities. In this paper attempts have been made to identify the biodiversity of seagrass associated fauna and identify the major resources caught in different fishing gears operated in the fishing areas. The study has evaluated the manpower involved in each fishing activity, the methods of operation and the impacts of such activities. Another objective of the study was to identify the conservation methods which are required to protect these natural habitats which are threatened by anthropogenic activities.

\section{Material and methods}

The GoM extends about $190 \mathrm{~km}$ and PB of $260 \mathrm{~km}$ along the southeast Indian coastline and are blessed with vast expanses of tropical seagrass beds. The PB is very shallow with depths ranging from 1 to 10 meters along the coastal areas and less than 20 meters in most other places. Seagrass beds in PB are present from near shore to $9 \mathrm{~km}$ towards seawards. GoM Biosphere Reserve comprises of 20 Islands and seagrass beds are found along the coastal area of 0.75 to 9 meters depth and evenly distributed along the islands. Coral reefs, seagrass and mangroves of GoM come under legal protection whereas the ecosystems present in PB area are not yet declared as protected area. The seagrass beds of PB (Mandapam to Adhirampattinam region) have more luxuriant growth of seagrass density than GoM. Underwater explorations have revealed that three types of sea grass beds are present in PB such as (i) Coral reef associated sea grass bed as observed in Mandapam area (ii) Mangrove associated sea grass beds in Adirampattinam, Mallipattinam and Sethubavachatram area and (iii) Shallow sandy bottom sea grass beds found in Thondi, Kottaipattinam and Jegathapattinam area.

The seagrass associated fauna were studied based on visual observation along the local landing centres. Underwater studies were conducted by visual census method described by Francour et al., 1999 using SCUBA diving. Published information were collated from various articles published by Central Marine Fisheries Research Institute (ICAR- CMFRI) since 1947.

Towards arriving at a derived assessment of fish and fisheries in a region dominated by sea grass beds, the catch of five selected fishery resource groups as reflected in their landings at the centres (Fig.1) dotting the area and the corresponding effort expended to catch and land them was collated and summarized. The centre-wise, resource wise figures collated were based on the landing centre- day and resource specific estimates arrived in 2015 using a comprehensive multi-stage sampling design. Using the values of the second stage sampling units viz. crafts landing in the select centres, the centre-year estimates of both landings and effort were estimated and summarized after analysis. The impact of shore seine operation in seagrass beds was studied during the year 2015 using SCUBA diving and documented through photography and videos. Shore seine catch landed at 4 sites in the year 2015 were analyzed for the present study. Many artisanal fishermen depend on seagrass beds for their livelihood. Their fishing activities like Cephalopod fishing locally called as 'kanava thoondi' and stake net fishery (adappu valai or patti valail) also observed by diving.

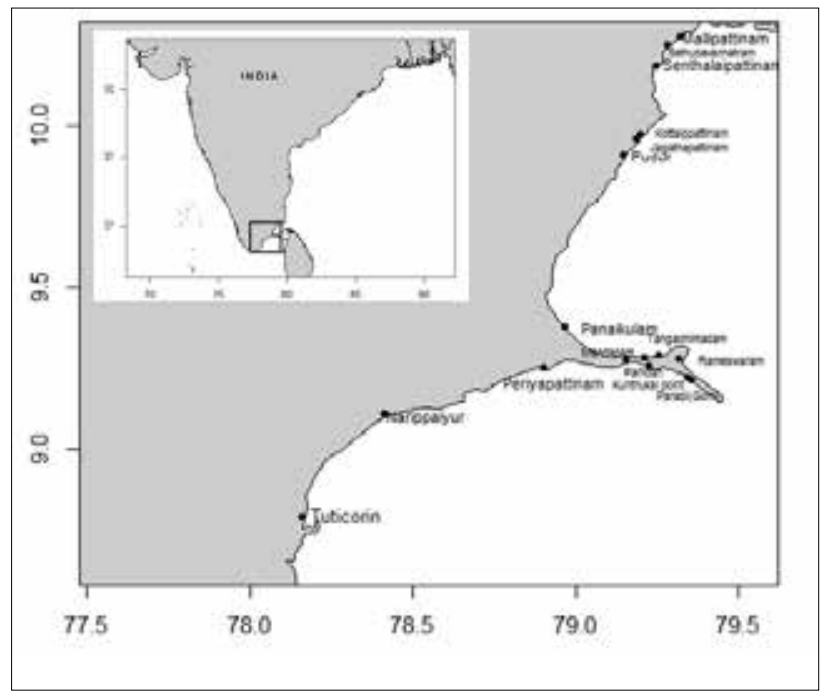

Fig.1 Map showing the location of study area.

\section{Results}

\section{Seagrass associated species}

Extensive field studies and collated information from different sources revealed that the seagrass associated species diversity was very high and also highlighted was the increased presence of endemic species (Kumaraguru et al., 2008). 
R. Jeyabaskaran et al.

\begin{tabular}{lll}
\multicolumn{2}{l}{ Table 1. Status of seagrass associated fauna } & \\
\hline Taxa & No. of Species & Endemic Species \\
\hline Foraminifera & 51 & 2 \\
\hline Sponges & 275 & 31 \\
\hline Coelenterates other than corals & 123 & 49 \\
\hline Polyzoa (Ascidians) & 100 & 15 \\
\hline Polychaetes & 75 & 22 \\
\hline Crustaceans & 651 & 159 \\
\hline Mollusca & 733 & 26 \\
\hline Echinoderms & 274 & 2 \\
\hline Pro-chordates & 66 & 41 \\
\hline Fishes & 580 & 0 \\
\hline Marine Mammals & 18 & 1 \\
\hline
\end{tabular}

The updated present status of diverse taxonomic groups is listed in Table 1.

Most of the marine protected species like dugongs, sea turtles, pipefishes, sea cucumbers, chanks and seahorses are mainly dependent on the seagrass beds. Seahorses, pipefishes, sea cucumbers and chanks are exploited through shore seine and shrimp trawling fishery. In PB alone, 5,300 kg year ${ }^{1}$ seahorses were reported to have been caught (Lipton and Thangaraju, 2002). The seahorse (Hippocampus kuda), pipefishes (Syngnathoides biaculeatus, Hippichthys cyanospilos, H. spicifen) are commonly found in seagrass beds of PB. The three species of sea cucumbers Holothuria scabra, H. spinifera and Actinopyga echinites are commercially important in GoM and PB. There are 5 species of seahorses and 9 species of pipefishes reported from GoM (Murugan et al., 2011).

The seagrass beds are housing many ornamental fishes and invertebrates. They have been exploited for live aquarium trade. The sea anemones (Sticodactylus haddoni and Hetractics magnifica); Pen shells (Pinna bicolor, Pinna deltodes and Pinna incurve); Starfishes (Pentaceraster regulus and Protoreaster lincki); Sea urchins (Salmacis virgulata, Stomopneustes variolaris and Temnopleurus toreumaticus); Soft corals (Lobophytum sp, Sinularia sp. and Sacrophyton sp.); Ornamental shrimps (Lysmata debelius, L. amboinensis, Ancylomenes magnificus, and Stenopus hispidus); sea slugs (Dolabella sp) are being heavily collected by local fishermen for aquarium trade. Aquarium traders in Mandapam, Madurai and Chennai are purchasing the live ornamental organisms from the fishermen. The gastropods (Pyrene flava, P. testudinaria, Euplica scripta, Cerithium scabridum and C. trailli) were found attached to the seagrass blades and shoots. The muricid gastropod Chicoreus virgineus var. ponderosa, Cypraea sp. also commonly found in the seagrass beds. The Venus clam (Gafrarium tumidum) generally found in the shores of GoM

and PB are being harvested by the fishermen for food and making lime.

Most of the marine protected species like dugongs, sea turtles mainly depend on the seagrass beds for their survival. The dugong (Dugong dugon Müller, 1776), commonly known as "sea cow", is a large marine mammal and is the only living member of family Dugongidae under order Sirenia. Dugong feeds mainly on seagrass species of the genera Thalassia, Enhalus, Cymodocea, Halodule, Syringodium, and Halophila. Stomach grabs of dugongs captured in the Gulf of Mannar and Palk Bay consisted of seagrasses Cymodocea serrulata, Syringodium isoetifoliam, Halodule uninervis, Halophila ovalis and Enhalus acoroides. Dugongs are restricted to inshore waters by their dependence on seagrasses. Dugongs are known as 'aavulia' in Tamil. They have been reported to be present in PB and GoM of southern Tamilnadu. Due to dependency on seagrass for their survival, habitats of dugong are more susceptible to increased pressure from human activities. Illegal hunting of dugongs is still going on in GoM despite stringent law in place. The dugongs are being killed by gillnets with large mesh size that are operated in the seagrass beds. Before the advent of nylon nets, gillnets were made by coir threads. Dugongs entangled in the nets could break the meshes of the nets and escape. But gillnets of today, made of nylon threads, are fatal for dugong. The marine mammals and seabirds are the apex predators in the marine ecosystem. The Indo-Pacific Hump-backed dolphin Sousa chinensis, Indo-Pacific bottlenose dolphin Tursiops aduncus and Finless porpoise Neophocaena phocaenoides were frequently sighted in the seagrass beds indicating their close association with this habitat.

\section{Seagrass dependent fisheries}

There are 16,560 fishing vessels which operated from the landing centres distributed alongside the seagrass habitats. Among these, 3744 gill netters and 3529 non-motorized vessels are fully dependent on seagrass habitats. The total landing of fishes in the year 2015 estimated from the 89 fish landing centres were $3,521,327 \mathrm{kgs}$. Apart from fin fishes, other commercial fishery resources from the seagrass habitats such as Penaeid Prawns-11381 t, Non-penaeid Prawns-2270 t, Squids-6751 t, Crabs- 9893 and Lobsters- $1170 \mathrm{t}$ were landed. Among these, the seagrass dependent fishery resources were landed in 10 major landing centres along the coastal stretch.

Tables 2 and 3 detail the quantum and categories of seagrass dependent resources landed and the type of effort expended to land them in the study area. It is quite clear from the percentage of quantity of sea grass dependent resources landed as against the total marine fish landings of the major landing centres of the zone under study of 2015 there is a distinct skew in the quantum landed seen in juxtaposition with total landings 
Table 2. Landing details of seagrass dependent fishery resources from Tamilnadu

\begin{tabular}{llllllll}
\hline Name of Landing Centres & Penaeid Prawn & Non-Penaeid Prawn & Lobster & Crab & Squid & Total Catch (kg) & Percentage (\%) \\
\hline Tuticorin & 429439 & 213419 & 20966 & 762564 & 1968385 & 3394773 & 20.16 \\
\hline Jagathapattinam & 2411308 & 0 & 0 & 331052 & 17212 & 2759572 & 16.39 \\
\hline Kottaippattinam & 2102420 & 0 & 0 & 252563 & 54910 & 2409893 & 14.31 \\
\hline Mandapam & 1506024 & 33582 & 0 & 710820 & 0 & 2250426 & 13.36 \\
\hline Mallipattinam & 1200145 & 0 & 0 & 214050 & 24003 & 1438198 & 8.54 \\
\hline Rameswaram & 934626 & 14784 & 0 & 225425 & 0 & 1174835 & 6.98 \\
\hline Pudur & 108099 & 0 & 0 & 924464 & 0 & 1032563 & 6.13 \\
\hline Senthalaipattinam & 0 & 0 & 0 & 915120 & 0 & 915120 & 5.43 \\
\hline Sethubavachatram & 628301 & 0 & 0 & 99881 & 15493 & 743675 & 4.42 \\
\hline Therkuvadi & 46933 & 0 & 3002 & 17655 & 653976 & 721566 & 4.28 \\
\hline
\end{tabular}

Table 3. Gear wise catches $(\mathrm{kg})$ of seagrass dependent fisheries

\begin{tabular}{lllllllllll}
\hline Gear & Tuticorin & $\begin{array}{l}\text { Jagatha- } \\
\text { pattinam }\end{array}$ & $\begin{array}{l}\text { Kottai } \\
\text { pattinam }\end{array}$ & Mandapam & $\begin{array}{l}\text { Malli- } \\
\text { pattinam }\end{array}$ & Rameswaram & Pudur & $\begin{array}{l}\text { Senth } \\
\text { alaipattinam }\end{array}$ & $\begin{array}{l}\text { Sethu Bava } \\
\text { chatram }\end{array}$ & $\begin{array}{l}\text { Therkuvadi } \\
\text { IBGN }\end{array}$ \\
\hline M250 & 0 & 0 & 0 & 0 & 0 & 0 & 0 & 0 & 0 \\
\hline MDTN & 0 & 321989 & 1824950 & 662210 & 169489 & 585621 & 0 & 0 & 21103 & 20336 \\
\hline MTN & 3321464 & 2437583 & 584944 & 1588216 & 1230667 & 573434 & 0 & 0 & 692430 & 701231 \\
\hline NMBSGN & 12200 & 0 & 0 & 0 & 0 & 0 & 0 & 0 & 0 & 0 \\
\hline NMGN & 429 & 0 & 0 & 0 & 0 & 0 & 0 & 0 & 0 & 0 \\
\hline NMHL & 1500 & 0 & 0 & 0 & 0 & 0 & 0 & 0 & 0 & 0 \\
\hline OBBSGN & 31007 & 0 & 0 & 0 & 0 & 0 & 918884 & 915120 & 4776 & 0 \\
\hline OBGN & 21848 & 0 & 0 & 0 & 38042 & 0 & 0 & 0 & 0 & 0 \\
\hline OBSS & 75 & 0 & 0 & 0 & 0 & 0 & 0 & 0 & 0 \\
\hline OBTN & 0 & 0 & 0 & 0 & 0 & 15780 & 113680 & 0 & 25367 & 0 \\
\hline Total & 3394773 & 2759572 & 2409894 & 2250426 & 1438198 & 1174835 & 1032564 & 915120 & 743676 & 721567 \\
\hline
\end{tabular}

IBGN-Inboard Gillnet; MDTN-Multiday Trawl net; MTN-Mechanised Trawl net; NMBSGN-Non Motorised bottom set Gillnet; NMGN-Non motorised Gillnet; NMHL-Non motorised Hook \& Line; OBBSGN-Outboard bottom set Gillnet; OBGN- Outboard Gillnet; OBTN-Outboard Trawl net

between the PB part and the GoM part. Tuticorin accounts for a significant 20.16 percent with steady fall in proportion while moving towards north. Jagathapattinam and Kottaippattinam are exceptions to this, logging close to $15 \%$. But a closer look at the gear profile will possibly give a clearer picture. Both these landing centres have landed the resources using trawl nets including the multiday ones, whose grounds could have been more southwards as usually the case has been. Also the gear profile of Tuticorin is a picture in contrast. With as many as seven gears playing a part in landing dependant resources, the local presence of seagrass beds is well underlined. The fact that highly short ranged and locally deployed non-mechanised gears (which neither use motor power either for propulsion or for fishing) have landed such resources albeit in a very low scale is an indicator enough of the wealth of seagrasses. The landings of such grass bed habitat resources by outboard units too reinforce the similar fact. This phenomenon is recorded in many centres of Palk Bay too.

Bottom Set Gill Nets (BSGN) have the second major ranking in terms of catchability coefficient of the focussed category of resources and hence doubly vouch for the strong presence of seagrass beds in those fishing grounds which can be covered in a day's fishing from the listed centres. It is a fact that trawl nets overshadow the quantum of captured resources and still if their dominance is offset by orthogonality, the rest of the gears recording non-zero landings do contribute to the second most influential component explaining the catch variability amongst the seagrass dependent resources.

\section{Cephalopod fishing}

Cephalopods consisting of squids, cuttlefishes and octopuses which too form an important commercial fishery in seagrass ecosystem. Squids and cuttlefishes locally called as 'kanava' are principally caught as by-catch from shrimp and fish trawls employed by the trawlers. The main squid species landed in GoM and PB are Sepioteuthis lessoniana (Silas et al., 1982). The luxuriant dense seagrass beds always attract squids and cuttlefishes, which are caught by the hand jigging operated from thermocol float (Fig. 2a). Fishermen use Japanese jigs 

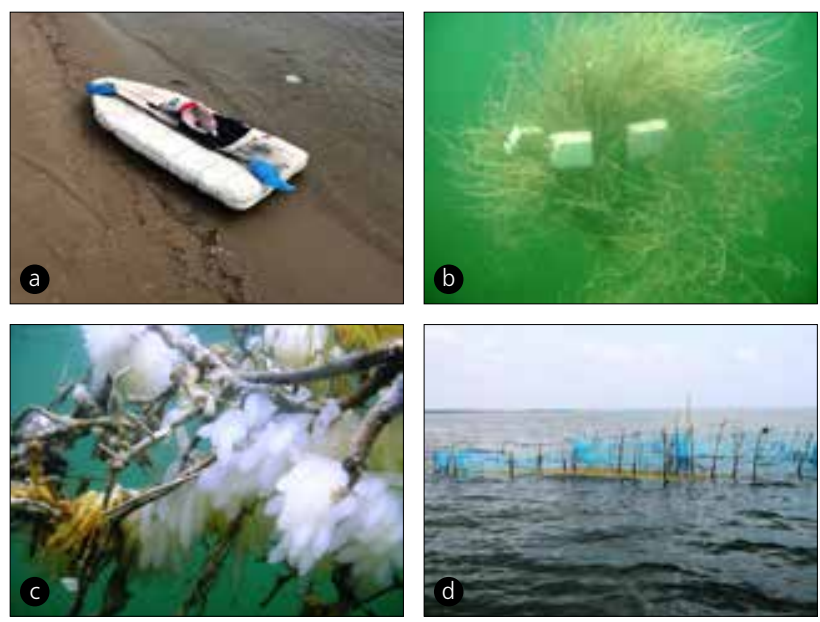

Fig. 2a. Thermocol float, b. Underwater photo of plant material FAD, c. Squid egg cluster attached in decayed leaves, d. Stake net/ Lead fish trap net.

which resemble live shrimp. Each jig is tied to nylon wire with length ranging from 6 to $15 \mathrm{~m}$ and is rolled on a wooden frame reel or spindle (Balasubramanian et al., 1995). Thermocol floats are made up of thermocol sheets and thermocol waste materials which are stitched together using nylon twine into particular shape. The entire set of floats is covered by polys sack which are sourced from empty cement bag or urea sack and tied strongly by small nylon rope. Thermocol floats have low weight and a single man handles them efficiently. Seagrass beds act as a best spawning ground for squids and cuttlefishes. Female cuttlefishes and squids move towards seagrass beds in search of substrate to attach their egg mass. The squid species $S$. lessoniana commonly called as Palk Bay squid is abundantly found in GoM and PB. The fishermen of GoM collect small plant materials from near shore area and tie them together by nylon rope. Small thermocol pieces are attached to the plant materials as shown in Fig. $2 \mathrm{~b}$ for keeping the plant materials in upright position. These plant materials are deployed in dense seagrass beds occurring in 2-3 $\mathrm{m}$ depth using sand filled sacks for anchoring (Fig. 2b). Sometimes fishers use stone as anchor material. These natural plant materials act as FAD. Female squids are attracted by the decaying plant leaves and lay the egg masses onto the branches (Fig. 2C). In PB, fishermen use bamboo shoots or coconut spadix as FAD. Underwater visual observation of present study revealed that individual egg capsule consists of 6 to 8 embryos. Each egg cluster consisted of 15 to 19 egg capsules and 32 to 40 such egg clusters per FAD unit was noticed. Peak spawning period of $S$. lessoniana was during post monsoon period of January to March and the activity gets extended up to June. The dominant cuttlefish species landed from the southeast coast of India is Sepia pharaonis, followed by S. aculeata (Geetha Sasikumar et al., 2015).

In the year 2006, cephalopod production in PB estimated as
584 tons with a mean catch per unit effort (CPUE) of $16 \mathrm{~kg}$. Squid catch was $54 \%$ followed by cuttlefish, which formed $46 \%$. In GoM, 230 tons of cephalopod were landed of which squid formed $71 \%$ and cuttlefish $29 \%$. The mean CPUE was estimated as $10.5 \mathrm{~kg}$ with peak landing during June to July (Venkatesan and Shanmugavel, 2008). During the present study, the CPUE of PB ranged from 6.5 to $20 \mathrm{~kg}$ and in GoM ranged from 4.5 to $11 \mathrm{~kg}$. Fishermen usually go for cephalopod fishing in the early morning and return before the sun sets. Sometimes, they go for fishing during night on full moon days. Seagrasses serve as nursery and breeding grounds of cephalopods. Seagrass disappearance in coastal area can directly lead to decline of cephalopod and indirectly affect the livelihood of fishermen who depend on cephalopod fishery.

\section{Stake net/ Lead-trap net fishery}

Lead-trap net or stake net fishing in GoM and PB is the emerging fishery propped by expansive seagrass beds. This type of fishery was introduced to GoM in the year 1990 by Sri Lankan refugees in Mandapam. In the year 2010, only 30 nets were operated in between Thangachimadam and Pudumadam (Venkatesan, 2010). The structure, fabrication, installation and economy of individual lead-trap net fishery were described by Venkatesan (2010). Sri Lankan Tamil people call this lead-trap net as 'pattivala' and local fishers call as 'adappu valai' (Fig. $2 \mathrm{~d})$. During the present study it was noticed that there were 60 nets installed between Thangachimadam to Periyapattinam. Now these types of lead-traps are found in PB seagrass beds also. A concerted study revealed the presence of about 52 nets in Mandapam to Mallipattinam stretch of PB. Underwater observation revealed the presence of following species in the net; Thryssa mystax, Grey Bamboo shark (Chiloscyllium griseum), Jellyfish (Mastigias cf. papua and Rhopilema cf. hispidum), Tetrodon fish (Canthigaster solandri), pufferfish (Arothron immaculatus, A. micropunctatus and Torquigener brevipinnis), orbicular batfish (Platax orbicularis), barracuda (Sphyraena sp.), squid (Sepioteuthis lessoniana), cuttlefish (Sepia aculeata and $S$. pharaonis), rabbit fish (Siganus canaliculatus, Siganus lineatus and Siganus javus) and sea snake (Hydophis sp.). There were instances of sea turtles accidentally entering into the trap net in search of food and getting trapped inside. It was observed during SCUBA diving sessions that Green turtle (Chelonia mydas) was found trapped in PB side of Mandapam and Olive ridley turtle (Lepidochelys olivacea) in Periyapattinam. Fishermen of these regions are well aware of the legal protection of turtles, albeit one off rare incidents of these turtles was being voluntarily collected for food in Kilakkarai and Periyapattinam.

\section{Crab and Shrimp fishery}

The brachyuran crabs and shrimps, particularly green tiger prawns, are permanent inhabitants of the seagrass ecosystem. Crab fishery is predominant in all the coastal areas of PB and 
GoM (Table 2). Crabs in seagrass beds are mostly exploited by artisanal fishermen through shore seine, push net 'thallumad? and bottom-set gillnet. PB and GoM fishermen use special type of gillnet called 'nandu vala' especially in Devipattinam, Thiruppalaikudi and Sethubavachatram, Senthalai pattinam, Pudur, Mandapam and Vedhalai by using country boat called 'vathar'. The 'nandu valar' is the monofilament gillnet with 80-90 mm mesh size (Josileen and Menon, 2007; Rajamani and Palanichami, 2010). The annual landing of crabs in the year 2015 at major landing centres are given in Table 2. The crab catch data is always higher in majority of locales in PB than in GoM, which were exclusively punctuated by Blue crab (Portunus pelagicus). The major share of GoM crab landing were P. pelagicus ( $-90 \%$ ) followed by P. sanguinolentus (' mukkannu nandu'), Charybdis natator, Scylla tranquebarica and C. feriata (siluvai nandu).

The most dominant species found in the area is green tiger shrimp Penaeus semisulcatus. There are three types of gears i.e shrimp trawl net, disco gill net and push net (thallu madi) operated in the seagrass beds targeting these resources. In PB and GoM, shrimp trawls mostly operated at 7 to $18 \mathrm{~m}$ depths. The green tiger shrimp $P$. semisulcatus is mostly exploited by the 'thallu madi', which resembles mini trawl net which is operated only in dense seagrass beds throughout the year at the depth of $5 \mathrm{~m}$. The migratory behaviour of green tiger prawn $P$. semisulcatus was studied by tagging and it was learnt hat seagrass beds were their favourable habitats and they stayed for longer period than Fenneropenaeus indicus (Maheswarudu et al., 1998).

Most of the shrimps (90\%) caught in 'thallu mad' were juveniles resulting in indiscriminate exploitation of the resource in seagrass beds (Rajamani and Palanichamy, 2009). Shrimp trawl net fishing is traditionally carried out in PB during April to October and this gets shifted to GoM during November to March. Green tiger shrimp contribute over $50 \%$ of trawl catch followed by Fiddler shrimp (Metapenaeus stridulans) (Maheswarudu et al., 1996). There are 59 species of shrimps identified in shrimp trawl net landings (Rajakumaran and Vaseeharan, 2014). Among these, Penaeus monodon, Fenneropenaeus indicus, Trachypenaeus pescadoreensis and Metapenaeus burkenroadi are landed in considerable quantities. Landing details of the year 2015 shows that shrimp landings were more in PB than GoM. The highest landings were reported in Jagathapattinam and Kottaipattinam followed by Mandapam (Table 2). The lowest landings were reported in Therkuvadi, where the seagrass density was less. It clearly shows the luxuriant seagrass beds are the nursery grounds of shrimps which contribute more catches. The Nonpenaeid prawns were landed only in Tuticorin, Mandapam and Rameswaram. The major contributor of non penaeid fishery was Paste shrimp (Acetes indicus) which are commonly found in seagrass beds.

\section{Shore seine/Beach seine fishing}

Shore seine/Beach seine fishing is locally called as 'kara valal' has been operated in seagrass beds of PB and GoM by artisanal fishermen for many decades. There are two type of shore seines operated in these areas. In the first type the net length is about $500 \mathrm{~m}$ and width is $3 \mathrm{~m}$ with mesh size of $10 \mathrm{~mm}$ to $30 \mathrm{~mm}$ made up of nylon thread. The bottom edge of net attached with thick coir rope or nylon rope for sinking the net to bottom. Generally 12-14 people are involved with 6 to 7 people on each side of net in the shore and jointly pull the net to sea shore (Fig. 3a). The shore seine fishing lasts for a minimum of 3 hrs of operation in near shore seagrass beds at the depths of 0.5 $\mathrm{m}$ to $3 \mathrm{~m}$ and normally they start at $5 \mathrm{am}$ and end at $8 \mathrm{am}$. If the catch is very less, they haul twice. Many fisherwomen are involved in these fishing activities. The type ' $b$ ' shore seine (Fig. $3 c$ ) is big size with 1 to $2 \mathrm{~km}$ length and small boat is engaged to deploy the net in the seagrass beds at the depths of 1 to 5 $\mathrm{m}$. The width of the net is about 4 to $5 \mathrm{~m}$ and the bottom edge of the the bag part is attached by iron chain and iron balls (Fig. $3 d)$ for efficient trawling in the seagrass beds. The top edge is buoyed by floats. There are 20 to 24 people involved and each side 10 to 12 people engaged to pull the wing rope. Nowadays, wing ropes are pulled with the help of tractors to reduce the human effort. To study the impact of shore seine on seagrass beds, underwater visual observation was made using SCUBA diving. The present study revealed that type ' $a$ ' shore seine operation had not affected the seagrass beds and no damage was noticed in seagrass blades. The worst part of the fishing was $70 \%$ of the catches were composed of juveniles and sub adults (Fig. 3b). Compared to type ' $a$ ' shore seine, type ' $b$ ' caused
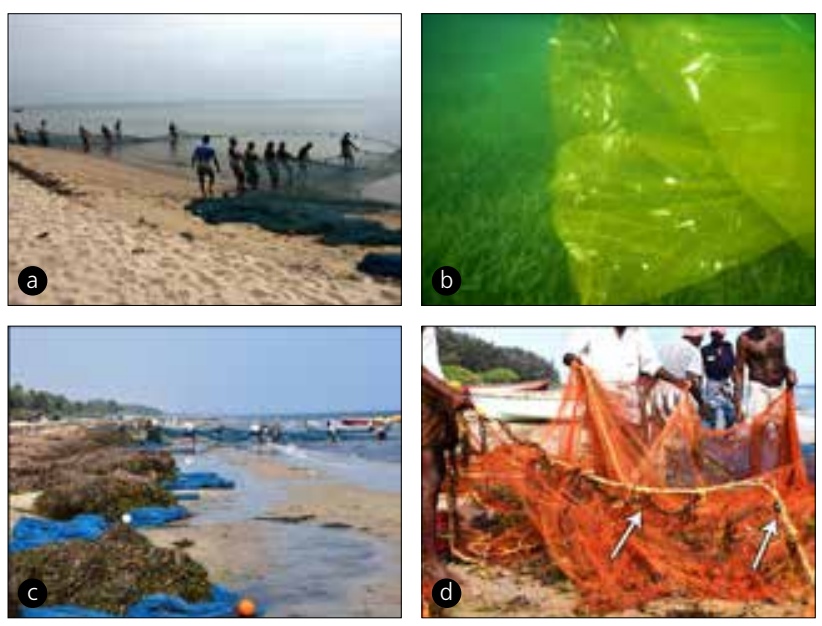

Fig. 3. a. Type 'a' shore seine operation, b. Juvenile fishes at the cod end of shore seine, $c$. Type ' $b$ ' shore seine fishing, $d$. Iron chain and balls attached to bottom edge of shore seine 
extensive detrimental effects to seagrass beds. Because of the metal chain attached to the bottom edge, it sweeps the bottom and breaking the seagrasses leaves/blades. Huge amount of seagrasses brought to the shore by this fishing operation and dumped in the shore (Fig. 3c). Along with seagrasses, many bottom dwelling animals such as polychaetes, molluscs, sponges, echinoderms were caught and dumped in the shore without any use. In the type ' $b$ ' shore seine fishing, catch ranged between 1 to 6 tons and more than $80 \%$ catch were juveniles and several non-commercial invertebrates. Repeated hauling in the area have caused extensive damages to the seagrass beds and will take long time to recover.

The shore seine catches of the 4 sites in the year 2015 was analysed. The sites were Panaikulam in PB, ii. RameswaramParadi (GoM), iii. Pamban-Kundukal point (GoM) and iv. Narippaiyur (GoM). Shore seines of type 'a' were operated in Pamban-Kundukal point and Rameswaram-Paradi. Shore seines fishing of type ' $b$ ' were engaged in Panaikulam and Narippaiyur. The CPUE was calculated in all the sites and variation of CPUE observed. The CPUE of Panaikulam was 139 kg, Rameswaram-Paradi- 237 kg, Pamban Kundukal point- $381 \mathrm{~kg}$ and Narippaiyur- $2010 \mathrm{~kg}$. Panaikulam seagrass beds once renowned for luxuriant growth of seagrass. Because of the repeated hauling of type ' $b$ ' shore seine, the seagrass beds have degraded and that has resulted in reduction of catches. The species composition of catches were analyzed and the results showed that the major catches comprised
Thryssa sp. which contributed to $72 \%$ of total catch, Indian oil sardine Sardinella longiceps (12\%), other sardines (7\%) and other minor group of species contributed to the tune of $9 \%$. The minor group consisted of 35 commercially important species and their catch details are plotted in Fig. 4. Among the catches, juvenile fishes of Eubleekeria splendens, Leiognathus brevirostris, Nuchequula mannusella and Gazza ninuta were dominant. Apart from fishes, squids (1\%), cuttlefishes (4\%), blue crabs P. pelagicus ( $\square 1 \%$ ) and miscellaneous species (4\%) were also recorded. In all there were 86 species reported in miscellaneous which mostly comprised sponges belonging the class Demospongiae, seahorses, pipefishes, echinoderms, molluscs and polychaetes.

Shore seining formed the base of what was locally called as 'kola' fishery. It consisted of three species Thryssa mystax, T. dussumieriand T. setirostris. The food and feeding habits of Thryssa sp. showed that adults prefers to feed on juvenile shrimps, Acetes sp., amphipods, fish eggs and larvae, molluscan larvae and polychaetes. The preferred food items of juveniles are nauplius larvae, Lucifersp., copepods, cypris larvae, alima larvae, amphipods and molluscan larvae. It has been reported that zooplankton densities in seagrass beds are twice that of offshore environments (Robertson et al., 1988). The seagrass beds of southeast coast of India consisted of thick biomass of zooplankton i.e $20-25 \mathrm{~m}^{-3}$ during October to December in PB and GoM, $17-20 \mathrm{~m}^{-3}$ during April to June (Maruthanayagam and Subramanian,

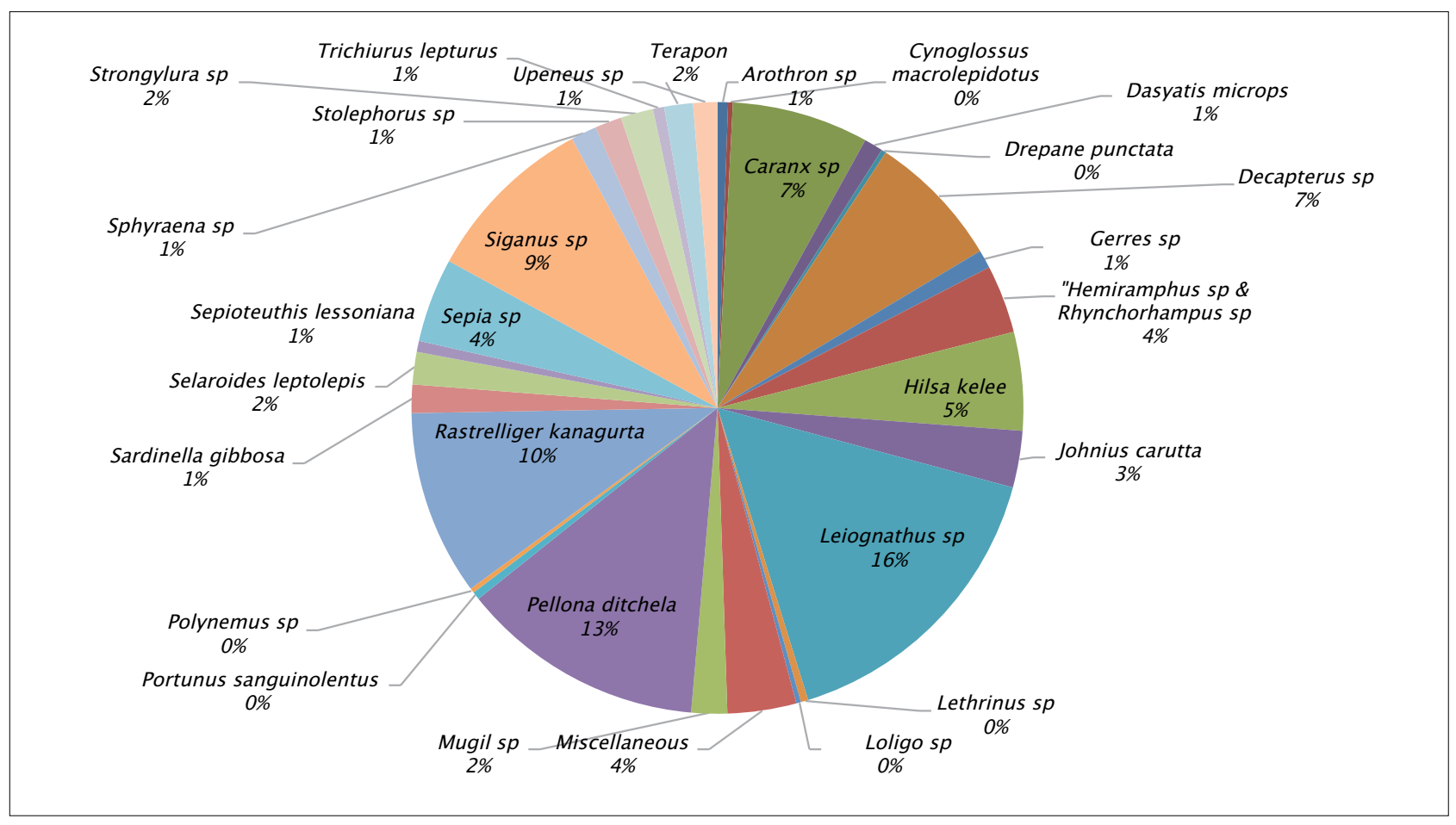

Fig. 4. Catch composition of minor groups recorded in shore seine fishery 
1999). So far, 114 species of zooplankton have been reported from GoM, in which copepods were dominant (Jeyaraj et al., 2016) and 43 species of diatoms and 2 species of blue-green algae recorded from PB. The food content of oil sardines collected from the shore seines were mostly copepods and the species Microsetella rosea was dominant in the diet. Juvenile oil sardines stomach was full of diatoms (Sekharan, 1971). It is very evident that seagrass acts as nursery and feeding grounds for Thryssa and oil sardines, which was reflected in the shore seine catch profiles.

The numbers of shore seines are increasing along the coast. The annual landing of shore seine fishing in the period 1987 to 1991 was 609 tons at Tuticorin (Bennet and Armugam, 1993). It has increased to 953 tones during the year 2012-13 (Diraviya Raj et al., 2017). In Tuticorin alone 610 fishermen are involved in shore seine fishing where the oil sardine and anchovies were the dominant catch contributors (Diraviya Raj et al., 2017). According to CMFRI (2012) fishery census 2010, there are 393 shore seines operated along the seagrass beds of GoM and PB. The fishermen profile and other details are given in Table 4 . It clearly shows that $75.45 \%$ fishers families depending on seagrass resources were Below Poverty Line (BPL) and 86,240 fishers are actually engaged in the fishing activities.

\section{Discussion}

The present study has established that seagrass beds support commercial fishing activities and also serve as biodiversity hotspots. Degradation of seagrass habitats has resulted in substantial loss of fishery and associated species. Since fishermen are wholly dependent on the resources, conservation of seagrass beds is possible only through their involvement. Many fishers are well aware of the fact that overexploitation of resources would ultimately be having a lasting negative impact on their income. But being sucked into the vicious cycle alternating between survival and sustainability they are forced into repeating the same due to their poverty. This gets more accentuated due to the fact that and there is no alternate livelihood income for them. On a comprehensive evaluation it is evident that the Palk Bay (PB) seagrass beds are luxuriant and diminishing faster than Gulf of Mannar
(GoM). This leads to the logical follow-up to ensure the identification of dense seagrass beds with high species diversity and abundance their legal protection in PB. Such stretches should be tagged as 'no take zone' and all fishing activities should be banned in that area. As an added benefit they will be helpful in conserving biodiversity aspect of seagrass beds while acting as spawning and nursery area for many fishes and invertebrates and perform as core zone. Concerted and comprehensive awareness programme among fishers is needed for setting this concept in motion. Awareness materials of underwater footage on destructive fishing practices, how it destroys the habitats and the consequences should be shown to them through fishermen societies. Special emphasis must be shown towards the endangered species 'sea cow (Dugong dugon) feeding habitats should be identified and protected. The fishing activities in vogue mostly involve small mesh size nets. Fishers should be educated to use large mesh size net and not to include metal chain in shore seine bottom edge, which increases their collateral lethality. Such steps would lead to avoidance of juvenile fishing and biodiversity loss. Government would better serve this cause to initiate a policy on 'Adopt a seagrass village' programme with the involvement of fishermen societies, $\mathrm{NGO}$ and industrialists. A major practical initiative could be the conceptualisation of model village for conserving the seagrass beds for others emulate. Conservation of seagrass beds could be achieved only through fishermen community participation. Legal protection and enforcement would best serve as invigorative mechanism for the positive orientation of fishers towards the management of the resources.

\section{Acknowledgements}

Authors are thankful to Director, ICAR-CMFRI for facilities provided. We are grateful to Dr. J. R. Bhatt, Advisor, MoEF\&CC, Govt. of India and Dr. T. Thangaradjou, DST-SERB for their moral support to bring out the paper. We are immensely thankful to Mr. K.G. Radhakrishnan Nair for his excellent field support.

\section{References}

Bell, J. D. and D. A. Pollard. 1989. Ecology of fish assemblages and fisheries associated with seagrasses. Biology of seagrasses, A.W.D. Larkum et al. (eds), Amsterdam: Elsevier Science, p. 565-597.

Bennet, P. S. and G. Arumugam. 1993. Small-scale shore seine fishery at Tuticorin: 1987-91. Mar. Fish. Infor. Serv., T\& E Ser.,123: 5 - 8.

Table 4. Fishermen profiles and number of shore seine operated in districts along the seagrass habitats

\begin{tabular}{llllllll}
\hline Name of District & Landing centers & Fishing villages & Fishermen families & BPL families & $\begin{array}{l}\text { Fisher folk } \\
\text { population }\end{array}$ & $\begin{array}{l}\text { Actual Fishermen } \\
\text { population }\end{array}$ & $\begin{array}{l}\text { Shore seine owned } \\
\text { by fishermen }\end{array}$ \\
\hline Thanjavur & 25 & 45 & 6530 & 6483 & 29489 & 7518 & 95 \\
\hline Pudukkottai & 30 & 33 & 6398 & 2689 & 29663 & 8222 & 4 \\
\hline Ramanathapuram & 90 & 178 & 41048 & 33429 & 193913 & 48753 & 221 \\
\hline Tuticorin & 27 & 32 & 19998 & 13212 & 82560 & 21747 & 73 \\
\hline Total & 172 & 288 & 73974 & 55813 & 335625 & 86240 & 393 \\
\hline
\end{tabular}




\section{R. Jeyabaskaran et al.}

Blanc, A. and J. Daguzan. 1998. Artificial surfaces for cuttlefish eggs (Sepia officianalis L.) in Morbihan Bay, France. Fish. Res., 38: 225-231.

Blasubramanian, T.S., S. Rajapackiam, H. Mohamed Kasim and K. M. S. Ameer Hamsa. 1995. Emergence of hand jigging for cephalopods along Tuticorin coast. Mar. Fish. Infor. Serv., T\&E Ser., 135: 13-16.

Diraviya Raj, K., S. Monolisha and J. K. Patterson Edward. 2017. Impacts of traditional shore seine operation along the Tuticorin coast, Gulf of Mannar, southeast India. Curr. Sci., 112(1): 40-45.

Edgar, G. J. and C. Shaw. 1995. The production and trophic ecology of shallow water fish assemblages in southern Australia. II. Diets of fishes and trophic relationships between fishes and benthos at Western Port, Victoria. J. Exp. Mar. Biol. Ecol., 194: 83-106.

Emma, L, Jackson., A. A. Rowden, J. M. Attrill, S. J. Bossey and M. B. Jones. 2001. The importance of seagrass beds as a habitat for fishery species. Oceanogr. Mar. Biol: An Annual Review, 39: 269-303.

Fonesca, M. S. and J. S. Fisher. 1986. A comparison of canopy friction and sediment movement between four species of seagrass with reference to their ecology and restoration. Mar. Ecol. Prog. Ser., 29: 15-22.

Fourqurean, J. W., C. M. Duarte, H. Kennedy, N. Marba, M. Holmer, M. A. Mateo, E. T. Apostolaki, G. A. Kendrick, D. Krause-Jensen, K. J. McGlathery and O. Serrano. 2012. Seagrass ecosystems as a globally significant carbon stock. Nat. Geosci., 5: 505 - 509.

Francour, P., C. Liret and E. Harvey. 1999. Comparisons of fish abundance estimates made by remote underwater video and visual census. Nat. Sicil., 23(Supplement): 155-168.

Jeyabaskaran, R., N. Raji, D. Prema and V. Kripa. 2014. Report on widespread occurrence of colonial epizoan ascidian Didemnum sp. in the seagrass beds of Gulf of Mannar. Mar. Fish. Infor. Serv., T\&E Ser., 222: 7-8.

Jeyaraj, N., S. Ravikumar, C. Rajthilak, S. Prasanna Kumar and S. Santhanam. 2016. Abundance and Diversity of Zooplankton along the Gulf of Mannar Region, Southeast Coast of India. Int. J. Mar. Sci., 6 (8) doi: 10.5376/ijms.2016.06.0028

Jose Josileen. and N. G. Menon. 2007. Fishery and growth parameters of the blue swimmer crab Portunus pelagicus (Linnaeus, 1758) along the Mandapam coast, India. J. Mar. Biol. Ass. India, 49(2): 159 - 165

Klumpp, D. W. and R. K. Howard and D.A. Pollard. 1989. Trophodynamics and nutritional ecology of seagrass communities. Biology of Seagrasses, A.W.D. Larkum et al. (eds), Amsterdam: Elsevier Science, p. 394-437.

Kumaraguru, A. K., V. Edwin Joseph, M. Rajee and T. Blasubramanian. 2008. Palk BayInformation and Bibliography, CAS in Marine Biology, Annamalai University, Parangipettai and Centre for Marine and Coastal Studies, Madurai Kamaraj University, Madurai, Tamil Nadu, India. 227 p.

Lipton, A. P. and M. Thangaraju. 2002. Present status of seahorse fishing along the Palk Bay coast. Mar. Fish. Info. Serv. T\&E Ser.,174: 5-8.

Rajamani, M. and A. Palanichamy. 2009. Need to regulate the thalluvalai fishery along Palk Bay, southeast coast of India. J. Mar. Biol. Ass. India, 51(2): 223-226.

Maheswarudu, G., E. V. Radhakrishnan, N. N. Pillai, M. R. Arputharaj, A. Ramakrishnan, S. Mohan and A. Vairamani. 1998. Tagging experiments on sea ranched Penaeus indicus in the Palk Bay, southeast coast of India. Indian J. Fish., 45(1): 67-74.

Maheswarudu, G., P. E. Sampson Manickam, P. Vedavyasa Rao and M. R. Arputharaj. 1996. (Observations on the exploitation of penaeid prawn resources in the Palk Bay off Mandapam during 1986-'93). Indian J. Fish., 43(3): 205-214.
Maruthanayagam, C. and P. Subramanian. 1999. Hydrological and zooplankton biomass variation in Palk Bay and Gulf of Mannar along the east coast of India. J. Mar. Biol. Ass. India, 41(1\&2): 7 - 18.

Waycotta, M., C. M. Duarteb, T. J. B. Carruthersc, R. J. Orthd, W. C. Dennisonc, S. Olyarnike, A. Calladinea, J. W. Fourqureanf, K. L. Heck Jr, A. R. Hughese, G. A. Kendricki, W. J. Kenworthyj, F. T. Shortk and S. L. Williamse. 2008. Accelerating loss of seagrasses across the globe threatens coastal ecosystems. PNAS, www. pnas.org cgi doi 10.1073 pnas.0905620106

Middleton, M. J., J. D. Bell, J. J. Burchmore, D. A. Pollard and B. C. Pease. 1984. Structural differences in the fish communities of Zostera capricorni and Posidonia australis seagrass meadows in Botany Bay, New South Wales. Aquat. Bot., 18: 89-109.

CMFRI. 2012. Marine Fisheries Census 2010 Part Il. 4 Tamil Nadu. CMFRI, Kochi, Kerala, India

Murugan, A., S. Dhanya, A. B. Sarcar, V. Naganathan, S. Rajagopal and T. Balasubramanian. 2011. Fishery biology, demography of three spotted seahorse, Hippocampus trimaculatus inhabiting Gulf of Mannar region, Southeast coast of India. Indian J. Geo. Mar. Sci., 40(3): 411-423.

Olney, J. E. and G. W. Boehlert. 1988. Nearshore ichthyoplankton associated with seagrass beds in the lower Chesapeake Bay. Mar. Ecol. Prog. Ser., 45: 33-43.

Rajakumaran, P. and B. Vaseeharan. 2014. Survey on Penaeidae Shrimp Diversity and Exploitation in South East Coast of India. Fish. Aquac. J., 5: 103. doi:10.4172/ 2150-3508.1000103

Rajamani, M. and A. Palanichamy. 2010. Current Status of Crab Fishery in the Artisanal Sector along Gulf of Mannar and Palk bay Coasts. In: Coastal Fishery Resources of India-Conservation and sustainable utilisation. Soc. Fish. Techno., p. 90-97.

Robertson, A. I., P. Dixon and P. A. Daniel. 1988. Zooplankton dynamics in mangrove and other nearshore habitats in tropical Australia. Mar. Ecol. Prog. Ser., 43: 139150.

Rooker, J. R., S. A. Holt, M. A. Soto and G. J. Holt. 1998. Post settlement patterns of habitat use by sciaenid fishes in subtropical seagrass meadows. Estuaries, 21: 318-327.

Geetha Sasikumar., K. S. Mohamed, Prathibha Rohit and G. Sampath Kumar. 2015 Policy guidance on cuttlefish fishery using Fish Aggregating Devices. Marine Fisheries Policy Series (1). Central Marine Fisheries Research Institute, p. 1 - 56, ISBN ISSN 2394-8019.

Sekharan, K. V. 1971. On the food of the sardine Sardinella albella (Val.) and S. gibbosa (Bleek.) of the Mandapam area. Indian J. Fish., 13 (1 \& 2): 96-141.

Silas, E. G., K. S. Rao, R. Sarvesan, K. P. Nair and M. M. Meiyappan. 1982. The exploited squid and cuttlefish resources of India-A review. Mar. Fish. Infor. Serv. T \& E Ser., 34: 1-16.

Venkatesan, V. and A. Shanmugavel. 2008. Note on hand jigging fishery for squids and cuttlefishes at Devipattinam in the Palk Bay and at Keelakarai in the Gulf of Mannar, south-east coast of India. Mar. Fish. Info. Serv. T\& E Ser., 197: 11-12.

Venkatesan, V. 2010. Emergence of shore fish traps 'pattivalal-their design and economics of operation along Mandapam coast. Mar. Fish. Info. Serv.T \& E Ser., 206: 11-14.

Webb, D.G. 1991. Effect of predation by juvenile pacific salmon on marine harpacticoid copepods. I. Comparisons of patterns of copepod mortality with patterns of salmon consumption. Mar. Ecol. Prog. Ser., 72: 25 - 36. 